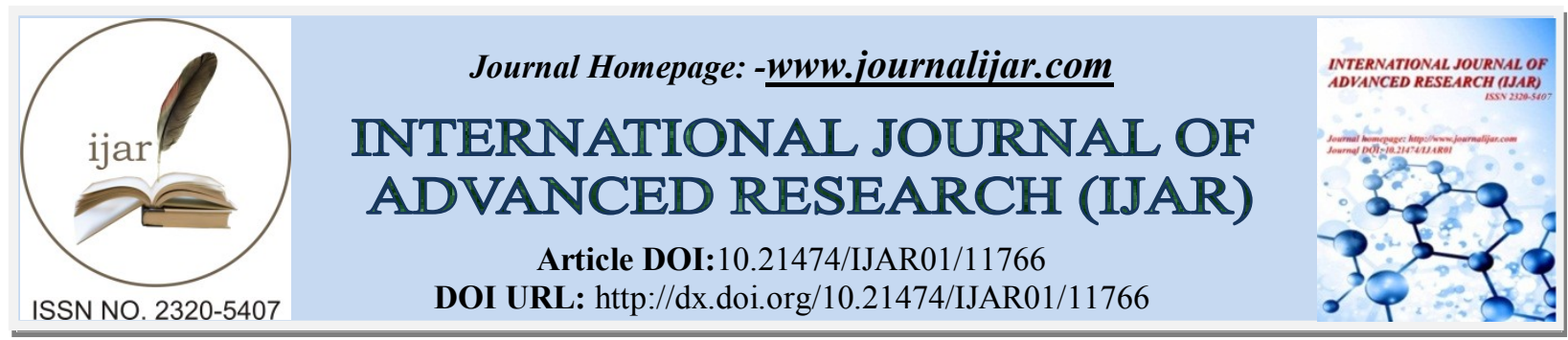

RESEARCH ARTICLE

\title{
POTTERY: A UNIQUE TRADITIONAL CRAFT IN INNER SIRAJ VALLEY OF NORTHWESTERN HIMALAYAN DISTRICT OF KULLU, HIMACHAL PRADESH
}

Sumati Rathore, Usha Thakur and Sarla Shashni

G. B. Pant National Institute of Himalayan Environment,Himachal Regional Centre, Mohal-Kullu, 175 126, Himachal Pradesh.

\section{Manuscript Info}

(...........................

Manuscript History

Received: 20 July 2020

Final Accepted: 24 August 2020

Published: September 2020

Key words:-

Pottery, Craft, Traditional occupation, Indigenous, Inner Siraj Valley, Kullu

\section{Abstract}

Pottery is a century old craft used by human and is one of the most tangible and iconic elements of Indian art. This craft system shows the lifestyle of native communities, their belief, faith, customs and tradition through their craft. This paper documents the traditional pottery art of the Sirajicommunity living in the inner Siraj Valley of Kullu district in Himachal Pradesh. The uniqueness of the art is wheels are not used for making different pots as in other parts of the country. Paper also documents the procedures involved in making the pots and its current status. Study revealed that this traditional craft system will not survive if some urgent measures are not be taken in near future.

Copy Right, IJAR, 2020,. All rights reserved.

\section{Introduction:-}

Traditional knowledge generally refers tothe cultural experience, creations, innovations and indigenous practices adopted by the native community of any region (Anonymous, 2002). Thispractice includes the traditional health care system, ethnobotanical knowledge, agricultural practices, climate knowledge, midwifery and various kinds of tools and techniques etc. (Mishra, 2006) which includes pottery also. This knowledge system on various aspects passes from one generation to next generation mainly orally (Anonymous, 1999; Geedh, 2013). Pottery in our country is also regarded as a very ancient craft of human civilisation(Hazra and Barman, 2017). The same can be recognised from the Neolithic Era with some of the beautiful examples of traditional pottery from ancient Indus valley civilization (Sekdar and Chaudhuri, 2015). From time immemorial, group of people commonly known as "Kumhaar" (Faley, 2013)uses clay with their bare hand to mould it into different shapes. There are various ethnic communities in the country who still practices pottery, which are culturally being transmittedfrom centuries (Khevaria, 2017).

Kullu district of Himachal Pradesh is famous for various types of traditional handicrafts such as bamboo basketry, pattu-making, pattal-making and pottery making etc (Sharma et al. 2008).In spite of an exhaustive work carried out on different traditional handicrafts in the region, no such attempts have been made on the traditional knowledge of pottery making. If effortsare not made timely to conserve the traditional knowledge of pottery, it will not survive. Therefore, a focused study is required to understand the entire procedure of pottery, current status, socio-economic conditions of people associated with it to conserve the time immemorial art and to facilitate people to continue using this art to preserve and flourish it.That's why the study has been conducted inFaryadi village of inner Siraj Valleywhich is known for its traditional potter's family.

Corresponding Author:- Sarla Shashni

Address:- G. B. Pant National Institute of Himalayan Environment,Himachal Regional Centre, MohalKullu 175 126. Himachal Pradesh. 


\section{Study area \\ Siraji Community in Faryadi Village}

Kullu is one of the twelve districts of Himachal Pradesh. It is one of the richest biodiversity areas of the State and supports one National Park (Great Himalayan National Park) and six Wildlife Sanctuaries i.e., Manali, Kanawar, Khokhan, Kais, Sainj and TirthanWildlife Sanctury(Singh et al. 1990). Itis very well known for itsforests, alpine meadows, gurgling rivulets, tiny fields and fruit orchards. Kullu district has been divided into five blocks viz. Naggar, Kullu, Banjar, Anni, and Nirmand. Total population is 4,37,474 as per 2011 Census comprising 2,24,320 Male and 2,13,154 Female (Census, 2011). The Northern part of the district is divided into two valleys i.e., outer Sirajand inner Siraj (Bhardwaj et al. 2014). In Inner Siraj Valley, one of the villages, called Faryadi is known for its traditional potter's family. The specialty of Sirajipotters is that they do not use any kind of rotating wheel for making wares contradictory to common practice. They perform it with bare hands with wooden stick. In this village, pottery production is mainly done in family units. Data collection was done in 2018 to 2019, through questionnaires, interview and field visits.

\section{Socio-Economic Profile of Faryadi Village}

The village is sparsely populated with 77 households with 33 general categories and 44 schedule caste family. From earlier times pottery is mainly done by the schedule caste population of the village whostillpracticingpottery for their livelihood.It was also found that the demand of the pottery products is decreasing due to the availability of relatively cheap plastic wares. This decrease in the demand of pots, these potters started shifting their economic activities to other activities like tourism, farming, etc.

\section{Results:- \\ Pottery: Ingredients and process}

Clay:

Traditional pottery requires locally available resources, such as clay as the primary material, firewood as fuel and other wooden implements (Dogan et al., 2008).Clay is a type of soil which is essential and cheapest raw material that is usedin pottery making (Gupta, 2008). The soil type used by the community for making pots is red clay which is locally known asLal-matta. They collect clayey soil from a particular mountain's creeks which are $10 \mathrm{Km}$ away from the village.According to the potter's clay of this area is soft and flexible hence easy to blend and mould.Areais quite far and difficult to approach as there is no pakka path and often, people carry clay on their back. This makes the process quite cumbersome and expensive/adds to the final cost. To get the desirable quality of clay, they dig ground around 1-3 meters depth and collect it. As per the potters the type of soil (red soil) needed for making pots are available in this part of the valley only.

\section{Water:}

It is used to easyly mixing and moulding ofclay into different shapes.

\section{Wood:}

Wood is the primary material used in fuel kilns for baking. All potters in the area uses especially Kail (Pinus wallichiana) and Chil (Pinus roxburghii) woods for baking. Teetne (Pine tree cones) and layers of grassesare also used during baking.

\section{Kiln:}

Use of a particular typeof fuel kiln/shed is the uniqueness of these potters which is made up of stone walls near the water source. It is locally known as odhi/gar. Thepotters usethese fuel kilns for baking pots traditionally and no modrn or gas fire unit is used. It is always constructed near the water source to maintain the temperature of the kiln due to the inflow of cool air from water source.

\section{Procedure}

As per their traditional belief, head of the family is mainly involved in the pottery craft and other family members work simultaneously. Male usually go to collect the clay and female members work on the clay preparation like clearing, drying, sieving,grinding, moulding, etc. They believe that if the clay is not prepared properly, pots break down easily even before the baking process. Therefore, clay is being made very carefully by slowly adding the water for rehydrating and blending it. The process is repeated till it reaches its desired smoothness. After that the clay is smashed with the stone tool called 'battu' until it is converted into fine and sticky form. Then they start making pots or different crafts by using their bare hand which is the speciality of this pottery system. In this traditional method of 
pottery, no rotating wheels are used which is usually being used in pottery making. Another uniqueness of this pottery system is pots or any craft they make it in two equal halves' separately and then join them together to make it one piece. As per the desired shapes potters beat the clay with a wooden plank from outside while placing one hand inside the clay. These wooden planks are of different sizes and shapes as per the shapes and requirement of pots (Fig. 1). Once a piece of pot is made, first of all it is dried in sun and then stacked and kept in the kiln. The entire stack is covered with teetne (Pine tree cones), a layer of grasses and wood one by one or sequentially or one after another. Then the fire is ignited to start the baking process. The entire baking process takes around one week.Aftercompletion of the process, the various pots/craft were sold in village level fairs and festivals. In some cases, potters also sell their crafts to the middleman for reselling.

\section{Type of crafts}

The pottery produces different useful products based on the requirement of the native people of different regions (Duary, 2008). These Siraji families still practice this craft from a very long time without any specific change in wares/craft making system. Different types of products (Fig. 2) and their uses are given below:

\section{Handi:}

A small pot used for various purposes.

\section{Charti:}

A big vessel used to make butter. Fresh curd or dhahi is put in the charti (matka) and churned. The first extract is lassi(buttermilk) and when churned more forcefully, the butter is made.

\section{Ghara:}

A big vessel used for storage of drinking water.

\section{Thuthi:}

Upper pot of $H u k k a$ (traditional tobacco smoking equipment).

\section{Gheyuli:}

Small vessel used to store ghee/Butter.

\section{Paru:}

A small bowl-shaped vessel used for pouring grains and pulses.

\section{Diya:}

Asmall earthen lamp that is used for worship of God.Oil/ghee serves as burning fuel and cotton wick is used for lightning of diyas.

\section{Traditional earthen pipe (Chilam):}

A straight conical pipe made up of clay. In the old days, monks and sadhus use this chilam for smoking purposes. Nowadays these are made ofdifferent metals. 

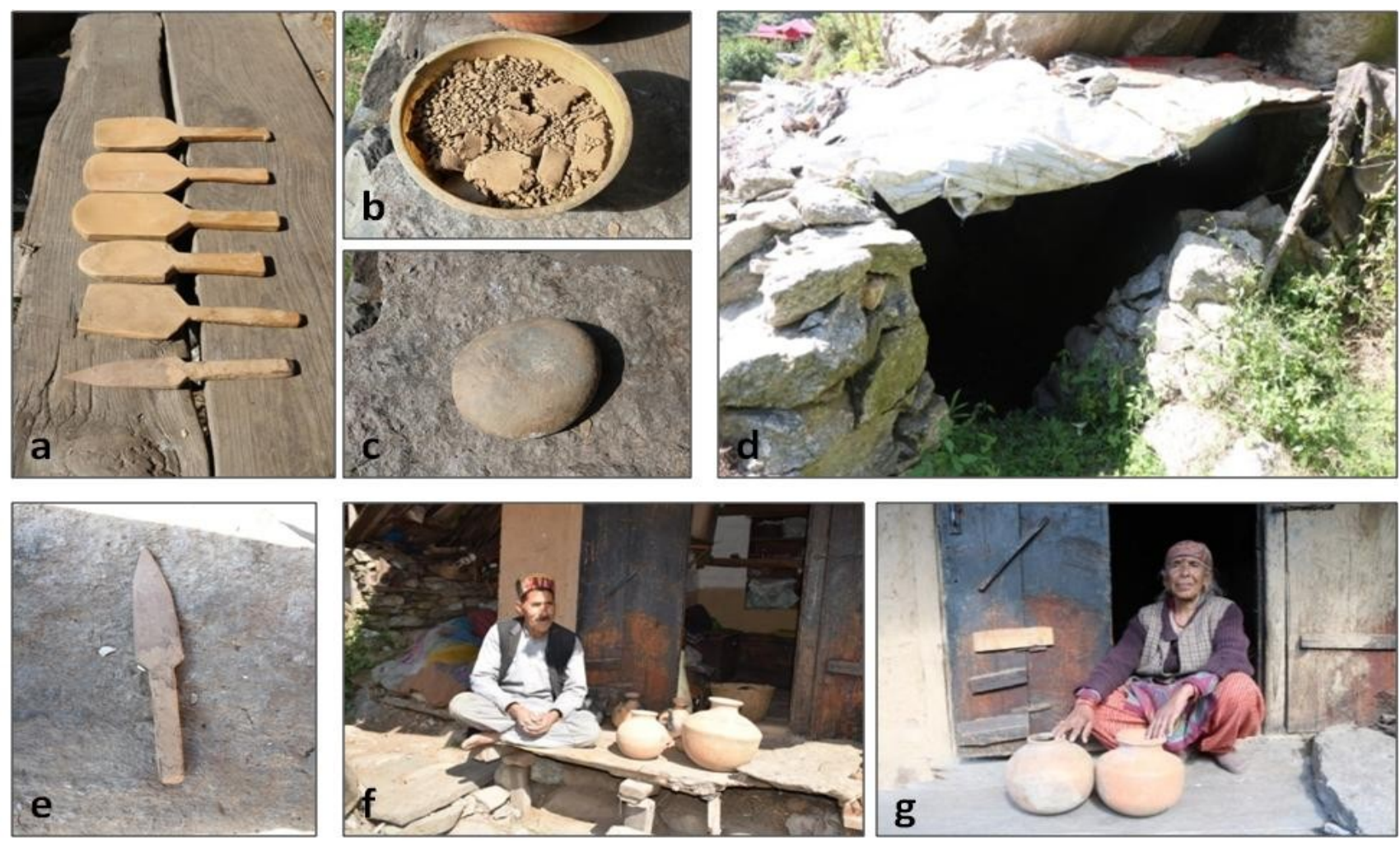

Fig. 1:- (a) Implements used (b) Clay (Lal-matta) (c) Stone (Battu) (d) Fuel Kiln (odhi/gar) (e) Kurpi (f\&g) Husband and wife involved in pottery making.
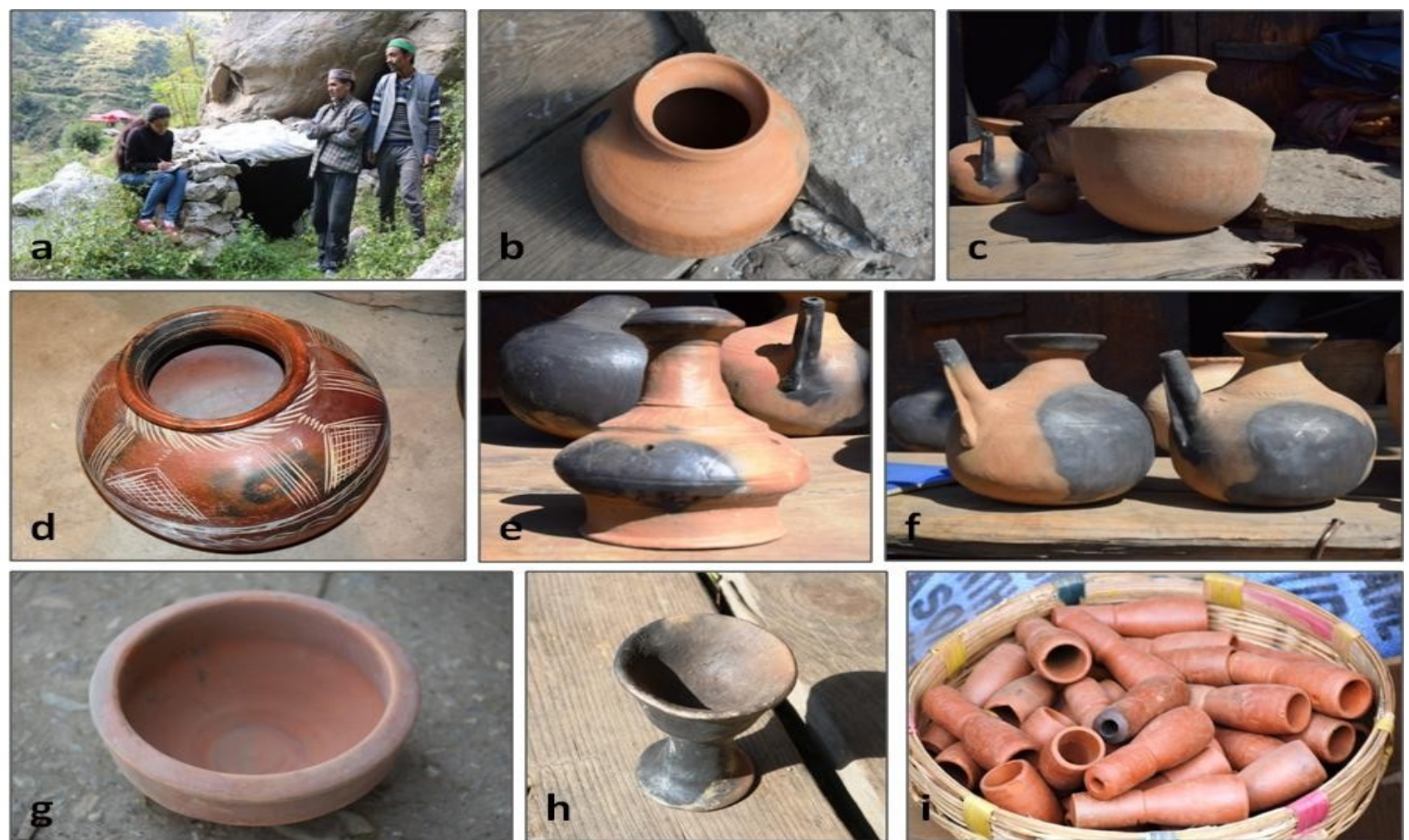

Fig. 2:- (a) Questionnaire survey (b) Handi(c) Matka for whey (Charti) (d) Ghara (e) Tuthi (f) Gheyuli (g) Paru (h) Diya (i) Traditional earthen pipe (Chilam). 


\section{Discussion:-}

Pottery in the region is unique itself as it is made without using wheel and at the same time its physically challenging and time consuming. Traditionally due to lack of economic inputs in terms of wheels and kilns natives continued the method as it was being practiced by their ancestors. Temperature regulation in the traditional fire kiln is one of the major issues which reduces their output up to 40 percent. Due to temperature fluctuation in the kilns only 60 percent of the pots come out properly. In last 3 to 4 decades, traditional ceramics are being threatened by modernisation viz. introduction of plastic wares and steel utensils which is cheaper. Also, lack of market and middleman reduce the income level so as the interest of potters. These factors led them to shift their occupation to other activities like tourism, farming and bamboo basketry for their sustainable livelihood. Lack of interest among younger generation towards the craft and occupation with high economic return also imposing a serious threat to this traditional craft of pottery in the region.

\section{Conclusion:-}

From the above study, it was concluded that the craft is slowly declining and in the forthcoming years if timely action has not been taken it will not survive in the near future.

\section{Recommendation:-}

This traditional pottery needs redesigning and technical adaptation to reduce the overall cost and time taken,only then this craft will act as a major source of income generation for this community which ultimately will conserve or promote the craft technique. There is also an urgent need to create linkages between organizations and markets for their crafts recognition and good returns.Financial aids for promoting the craft through various fairs, festivals and trade fairs areneededto conserve, facilitate, revive and revitalize this traditional craft of the region. This traditional technique also requires a stable place for the kiln and modern or better kiln with thermoregulation. This will minimize the breakage during baking process and cost of production plus time involved. Value addition in terms of diversity in the products and its looks will also fetch a good market price for the produces which will in return conserve and flourish this traditional pottery of the region.

\section{Acknowledgment:-}

The authors are thankful to Dr. R. S. Rawal, Director, G. B. Pant National Institute of Himalayan Environment, Kosi-Katarmal, Almora, Uttarakhand, India for providing necessary facilities. We are highly thankful to the Department of Science and Technology for financial assistance through NMSHE Task Force 5. We also appreciate the cooperation of the potters andlocal villagers for their help and providing necessary information during the field survey.

\section{Conflict of interest:}

Authors declares there is no conflict of interest.

\section{References:-}

1. Anonymous (1999):Final Declaration report of UNESCO on Protection of Traditional Knowledge and Expressions of Indigenous Cultures.

2. Anonymous, (2002): Report on Intellectual Property and Traditional Knowledge, (WIPRO).

3. Bhardwaj, A.,Rani, S. and Rana, J.C. (2014): Traditionally used common fibre plants in outer siraj area, Himachal Pradesh. Indian J Natural Products and Resources. 5(2): 190-194.

4. Census, (2011): Primary Census Abstracts, Registrar General of India, Ministry of Home Affairs, Government of India, Available at: http:// www.censusindia.gov.in.2011.

5. Dogan, Y.,Nedelcheva,A.M., Dragica, O.P. andPadure, I. M. (2008): Plants used in traditional handicrafts in several Balkan countries. Indian J Traditional Knowledge 7(1): 157-161.

6. Duary, N. (2008): Traditional Hira potters of lower Assam. Indian J Traditional Knowledge, 7(1): 98-102.

7. Foley, B. (2013): The Social Lives of Pots and Potters in the Kathmandu Valley.

8. Geedh, S.(2013): Contemporary Traditional Pottery Practices at Archaeo-Historically Important Sites, District Khargone, Madhya Pradesh. International Journal of Modern Physics: Conference Series, 93-98.

9. Gupta, C.S. (2008): Clay-traditional material for making Handicrafts. Indian J Traditional Knowledge, 7 (1): 116-124.

10. Hazra, K. K. and Barman, A. (2017): Prospect of traditional craft in present economy: A study of earthen doll of Krishnagar, West Bengal. International J Management, 8 (4): 75-81. 
11. Khevaria, K. (2017): Folk Handicrafts of the Ceramics City - Khurja. J Advances and Scholarly Researches in Allied Education, 1: 2230-7540.

12. Mishra, A. (2006):Time, Tradition and the Wheel: The Potters' Technology of Central India. Past and Present: Ethnoarchaeology in India, New Delhi: Pragati Publication, 269-302.

13. Sharma, N., Kanwar, P. and Rekha,A. (2008): Traditional handicrafts and handloom of Kullu district, Himachal Pradesh. Indian Journal of Traditional Knowledge, 7(1): 56-61.

14. Sikdar, M. and Chaudhuri, P. (2015): Pottery making tradition among the Prajapati community of Gujarat, India. Eurasian J Anthropology, 6(1): 1-14.

15. Singh, S., Kothari, A. and Pande, P. (1990): Directory of National Parks and Sanctuaries in Himachal Pradesh, management status and profiles. Environmental Studies Division, Indian Institute of Public Administration, New Delhi. 